\title{
Global Mindset: An Entrepreneur's Perspective on the Born-Global Approach
}

\author{
Robert Poole
}

\author{
"It is not necessary to change. Survival is not mandatory." \\ W. Edwards Deming (1900-1993) \\ Professor of statistics, author, and consultant
}

\begin{abstract}
The born-global approach calls for a startup to address the needs of a global market from inception. This approach provides an attractive alternative to the conventional staged approach to internationalization whereby a startup first operates in its home market and then enters one or more foreign markets sequentially. This article highlights the mindset change that an entrepreneur must make to move from the conventional staged approach to the born-global approach. The author of this article is an experienced entrepreneur and the article describes his own mindset change that occurred when enacting the born-global approach. The author uses his own experience and company as a case study to develop recommendations for other entrepreneurs who are evaluating the born-global approach to launch and grow a technology company.
\end{abstract}

\section{Introduction}

The born-global approach requires entrepreneurs to think and act globally from inception. In this article, I summarize the principles underlying the born-global approach and retrace my own journey as an entrepreneur to a greater appreciation of how early and rapid globalization can increase the chances of success for a new technology startup. Beyond knowledge acquisition and strategy development, a key element of this journey was a mindset change that was necessary to fully embrace the born-global approach.

Most entrepreneurs are comfortable with the idea of launching their startups to address the needs of a local market. There, they can grow and fine-tune their market offers and internal operating systems. Foreign expansion occurs only once the company is sufficiently large and mature and has learned how to serve the needs of the local market.

The notion of starting a company that is global from day one is daunting. At first it seems to present challenges that are impossible to overcome. There is the risk that the entrepreneur's efforts become unfocused or spread too thinly over many activities. The reluctance to establish a global company from inception is understandable once you accept that the entrepreneur is used to a mindset anchored around the conventional approach to internationalization.

The born-global approach requires a change in mindset, not just a change in business or product strategy. A born-global mindset allows entrepreneurs to define and act on global opportunities at an early stage in their companies' life cycle. However, entrepreneurs cannot be expected to make a sudden "leap of faith".

In this article, I describe my own gradual change in mindset, which began with lessons from my own entrepreneurial experience even before I was introduced to the born-global concept. I hope this article will be of interest to entrepreneurs about to start companies, but also to entrepreneurs with existing businesses.

This article is structured as follows. First, I describe my own background and the entrepreneurial experiences that triggered an initial shift in my mindset with respect to internationalization. Next, I offer six recommendations for entrepreneurs based on my experience, the 


\section{Global Mindset: An Entrepreneur's Perspective on the Born-Global Approach}

Robert Poole

principles underlying the born-global approach, and the related internationalization strategies we are currently implementing in my company.

\section{Lessons from Experience}

As an entrepreneur and co-founder of three technology startups, I have been part of management teams that have raised over $\$ 4$ million through multiple rounds of financing, executed a strategy through a reversetakeover to become a publicly traded company, and sold over \$2 million in products and services to companies in Canada, the United States, and Europe. Our customers have included the Canadian government, NASDAQ and American Stock Exchanges, Flextronics, Raytheon, General Electric, and American Express. By some standards these may be considered modest achievements; however, these experiences have taught me a great deal about starting and growing technology companies.

Early on, my co-founders and I had a conventional mindset with respect to internationalization. Our thinking as entrepreneurs and founders was to first find customers in Canada (our home country) and in the large adjacent market of the United States, where possible. Although we recruited resellers in Australia and an original equipment manufacturer (OEM) as a partner in the United Kingdom, our strategy and the vast majority of our early efforts were focused on the domestic market. We considered foreign markets as opportunities only when they presented themselves on an ad hoc basis through sales leads or when potential foreign partners reached out to us. Although reaching the U.S. market required us to step out of our domestic sphere, this still represented a limited global step given the country's proximity and similarities with Canada relative to other foreign markets.

For many Canadian technology companies, penetration into the United States is important because its market is 10 times the size of the Canadian market. The Canadian market is typically not seen by large or institutional investors as sufficiently large to provide a compelling proof point for a high-potential, fundable business.

For an investor, the best proof point of the attractiveness of an opportunity is evidence of global sales. Investors have told us over the years that they require the minimal addressable market opportunity for a business to be $\$ 1$ billion. A market of that size, combined with a well-differentiated product or service and a superior value proposition, makes it possible to have a shot at creating a company of sufficient size to make it worth their while to invest their money.

As we made dozens of presentations of our opportunities to potential investors in the United States, our mindset began to shift as we gained an increasing understanding of the challenges and benefits of globalization. In many cases, a global market makes an opportunity far more attractive than if the opportunity just targets the domestic market. We began to realize that the earlier we could access global markets, the greater the likelihood of our company's long-term success. Although we were not aware of the born-global approach at the time, our early experiences "prepared the ground" in terms of each of us becoming personally more receptive to early or rapid internationalization strategies.

A further evolution of my own mindset has been accelerated through the launch of a new Canadian company with the same group of co-founders: Freebird Connect (freebirdconnect.com). Freebird Connect builds upon experience and knowledge from its predecessor, but addresses new markets with a new business model (Poole, 2011; timreview.ca/article/446). Freebird Connect provides cloud-based software that combines data visualization (business intelligence) with collaboration and social networking to help organizations unify information and generate knowledge. Our company solves specific economic development problems for municipalities and for original equipment manufacturers and reseller partners (Box 1).

In the next section, I offer six recommendations for entrepreneurs based on the principles underlying the born-global approach. These principles have influenced our approach to the globalization of Freebird Connect. At the moment, Freebird Connect is probably best described as a hybrid between a conventional and born-global company, although the tides are increasingly shifting toward a more global approach. Knowledge of the born-global principles has greatly influenced a further shift in my personal mindset with respect to the benefits of early and rapid globalization.

\section{Recommendations for Entrepreneurs}

In this section, I offer six recommendations for entrepreneurs based on my experience applying the bornglobal approach to my own company. These recom- 


\section{Global Mindset: An Entrepreneur's Perspective on the Born-Global Approach}

Robert Poole

mendations highlight key areas where my own mindset needed to shift to take full advantage of the born-global approach and provide examples of the six elements described by Bailetti (2012; timreview.ca/article/614). It is my hope that these recommendations will help entrepreneurs in their own efforts to profit from their startups operating in global markets.

\section{Instill a global mindset throughout the company from inception}

Develop global opportunities from the moment your company is conceived; "local" is a small part of "global". Although these are early days for our startup, we apply the born-global principles when our management team discusses strategy. When we discuss "local" opportunities, we do so as if they were special instances of "global" opportunities.

Ideally, a global mindset should pervade the company from the start, including all of the founders and employees. Without a global mindset, the founders will not put in place all of the requisite processes throughout the organization to serve foreign customers and to capture all of the available knowledge from foreign sources. All of the founders of Freebird Connect understand that, to grow globally, we need a global orientation. Our current mindset stands in sharp contrast to our previous mindset where we only looked to foreign markets when opportunities presented themselves in an ad-hoc manner.

\section{Seek out individuals with international experience}

A global business requires a global network of relationships that can be leveraged to find customers, champions, and partners. This is where many immigrants to a country have a significant advantage over domestic entrepreneurs who likely do not have international experience, knowledge, or relationships. Previously overlooked groups (e.g., new immigrants, foreign Chambers of Commerce, trade officials from foreign embassies, universities, international associations) become critically important during the start-up phase of a born-global company. Similarly, hiring employees with international experience can provide important knowledge and experience.

For Freebird Connect, company champions are particularly important. A company champion is someone who is not likely to buy the company's product or service, but recognizes the value that the product or service provides their organization. Champions understand the problem solved and they are in a position to help the startup in a number of ways. For example, a cham-

\section{Box 1. Impact on Economic Development}

Born-global companies are economic development engines, particularly when seen from the perspective of a municipality. A local business that employs people is good for the local economy, and job creation is an important measure of successful economic development for municipalities. However, a business that also brings cash into a local economy from outside its borders is a far more powerful type of economic development agent. Municipalities can leverage born-global companies to drive local economic growth.

Municipalities also happen to be key target customers for our Freebird Connect platform, as described in the author's previous articles on economic development (Poole, 2010; timreview.ca/article/391) and on the Freebird Connect platform (Poole, 2011; timreview.ca/ article/446).

Our platform can help municipalities develop their economies, but we also believe that it can be used as a platform to help born-global companies in the following ways:

1. Provide entrepreneurs with processes for applying the born-global principles.

2. Create public and private communities of customers, partners, and champions that unify their collective knowledge and insight and work together to achieve discrete, mutual objectives.

3. Capture, analyze, and report on those key performance indicators that determine the health and effectiveness of an entrepreneur's born-global initiative.

In this way, the economic-development impact of Freebird Connect taking a born-global approach can be measured in three ways: i) when we generate cash and jobs in our own local economy, we act as an economic development engine for our own municipality of Ottawa, Canada; ii) when other municipalities use our platform, we contribute to economic development initiatives around the world, and iii) when companies use our platform to become born global, we contribute to further economic development around the world. 


\section{Global Mindset: An Entrepreneur's Perspective on the Born-Global Approach} Robert Poole

pion could help a startup find potential customers or investors, refine its value proposition, and assist with pricing or other contractual issues.

An entrepreneur needs to assess their current global networks and create a strategy to form new networks to pursue global opportunities. As part of our company's internationalization strategy, we will be creating a global network by accessing the organizations and groups where potential customers and partners interact. As one example, we can easily find out which universities are involved in research that is relevant to our company. As described in Box 1, economic development is one of the markets that our company addresses, so we are seeking out researchers and academic programs that are active in this area. When seeking global OEM partners, we also look for startups that have recently received significant funding. These companies have access to cash, but may likely lack the people and the capability to execute.

\section{Ensure that the problem is small enough to be solved by your startup}

Most entrepreneurs are overly optimistic. While this trait can be an asset to an entrepreneur, it can also be fatal because it can lead the entrepreneur to create a business that cannot succeed. Huge aspirations propel the entrepreneur to try to create a large business too soon. The size of the problem that the entrepreneur intends to solve at the start must be solvable by a startup. This is not to say that the startup founders cannot have huge aspirations and plans to eventually provide solutions that compete with established incumbents, but a small startup must be realistic about what it can actually achieve during the early phase of its life cycle. The right strategy is to find a small-but-significant problem that a startup can solve as a first step to solving more and possibly larger problems.

The problem must not only be small enough to be solved by a small startup company, the problem must be clear and well defined. Moreover, the startup must have a clear solution - ideally with a quantifiable return on investment for customers who pay for your solution. This can be hard to do. At Freebird Connect, we are continually working to define and refine the problems that we solve for our customers and partners (and our partners' customers).

\section{Sell a minimum viable product to foreign customers early}

Start selling a minimum viable product or service to foreign customers who have the greatest need for what you are selling. A minimum viable product or service is an offer that generates revenue for the company and that motivates customers to provide feedback and recommend it to other potential customers (Rancic Moogk, 2012; timreview.ca/article/535).

Many startups tend to spend too much time creating, modifying, and enhancing a product before it is ever seen by a customer. This is especially true if the founders have a technical background. In some cases, technical entrepreneurs devote too much attention to product refinement simply because selling is hard and they dread the unpleasant challenge of cold-calling potential customers. The born-global approach drives entrepreneurs to leverage global relationships and networks. Not only can these relationships remove or lower the barriers to sales, they can generate new knowledge that the entrepreneur can use to better understand the problem as it exists and to generate referrals to others who share the problem. It is better to begin selling a minimum viable product and take advantage of these relationships than to spend too long on refinements that may never bring a return.

A born-global company should use its minimum viable product to leverage each foreign customer to earn money, receive customer-driven feedback on what changes or modifications are required based on the customer's experience, and ask customers for referrals to others with the same problem. In order for Freebird Connect to internalize this approach, we have been studying the principles of referral selling because this established and accepted sales strategy is aligned with the born-global approach.

Traditional startups often look to heavily discount their market offer or give it away for free in exchange for testimonials. The problem with this approach is if a customer does not have to pay or pays little, then either the definition of the problem or the solution to the problem has not been adequately validated. The situation where an organization pays little or close to nothing for something that is a "nice to have" or as a favour to a young, pleading, passionate entrepreneur is very different than a situation where a customer pays market value for a product or service. If the problem is real, and the offered solution is real, then people will pay.

\section{Leverage the assets of well-established companies}

Leverage the assets of established firms with global operations to gain access to foreign customers and networks. These assets include product and technology platforms, Internet forums, brands, and open source 


\section{Global Mindset: An Entrepreneur's Perspective on the Born-Global Approach}

\section{Robert Poole}

communities. Large product platforms have global users, developers, and partners, and they are localized to many different languages. Open source software can provide both important infrastructure capabilities such as e-commerce and localization, but it can also give access to diverse, active, and global communities of developers, users, and champions.

\section{Develop a business model that is global, not local}

A born-global approach is much more than an export strategy. Develop a business model where you acquire and sell products and services in different geographies. Pretty much anything "as-a-service" is an excellent candidate for a born-global company. The possibilities include software-as-a-service (SaaS), infrastructure-as-a service (IaaS), platform-as-a-service (PaaS), or backendas-a-service (BaaS). With Freebird Connect, we decided at the beginning of our new, pivoted startup, that we would base our business model on a cloud-based software-as-a-service. Given that we were searching to create a way for our customers to collaborate and connect qualitative information to quantitative data, a softwareas-a service business model fit our global aspirations.

\section{Conclusion}

This article describes the mindset change I have undergone with respect to my views on early and rapid globalization. Looking back on the seven or so different businesses that I have started since completing my undergraduate degree (not including my consulting practice), I can trace my journey and how my perspective on startups has changed from "local and limited" to "global and practically unlimited". My first few businesses served only the local market in the city I lived in. My last business sold products and services primarily to entreprise customers in the country I lived. My current business has been designed from inception to be able to serve global customers and it is easily scalable. If you are going to invest thousands of hours of human effort into a business, it makes sense that you create the business that has the greatest chance of succeeding. Local and domestic markets are insufficient. Tilt the odds in your favour and globalize your startup early and rapidly. The born-global approach provides an entrepreneur with two important advantages. First, the approach provides a powerful framework to help an entrepreneur go through the process of launching and growing a global business. Second, the approach requires the entrepreneur to think differently about creating and launching a startup. It requires a personal transformation in entrepreneurial mindset and perspective.

The purpose of this article has been to help prepare the minds of entrepreneurs so they look at the process of creating a global company differently. My journey as an entrepreneur is not over; I am still learning. In this article, I share recommendations developed based on my experience. On the surface, some may perceive the born-global approach as being similar to the conventional approach of phased internationalization. As shown in this article, they are very different approaches. The born-global approach holds real promise of becoming an important driver of local economies by helping entrepreneurs create and grow successful companies worldwide.

\section{About the Author}

Robert Poole is an entrepreneur, a chartered accountant, and a recent graduate of the MEng program in Technology Innovation Management at Carleton University in Ottawa, Canada. Robert has 15 years of experience building and deploying business intelligence and social analytic solutions to global enterprises. As a consultant, Robert has provided his expertise to private and public-sector clients including federal, provincial, and regional governments. As an entrepreneur, Robert has created several technology-related companies and has appeared on CNBC's Power Lunch. Robert combines knowledge learned at the university with his practical experience to improve the fortunes of his company: FreebirdConnect.

Citation: Poole, R. 2012. Global Mindset: An Entrepreneur's Perspective on the Born-Global Approach. Technology Innovation Management Review. October 2012: 27-31. 